\title{
NEWLY DISCOVERED AND EXCEPTIONAL CIRCUMSTANCES IN CRIMINAL PROCEDURE OF SOME EUROPEAN STATES
}

\author{
Nazar Bobechko, Alona Voinarovych and Volodymyr Fihurskyi \\ nazar.bobechko@Inu.edu.ua \\ alona.voynarovych@Inu.edu.ua \\ volodymyr.fihurskyy@lnu.edu.ua
}

Summary: 1. Introduction - 2. The Essence and Models of Proceedings Based on Newly Discovered or Exceptional Circumstances in the Criminal Procedure of Some European Countries. - 3. Procedural Features of the Proceedings Based on Newly Discovered or Exceptional Circumstances in the Criminal Justice System of Ukraine. - 4. The Concept, Tasks, Significance and the Structure of Proceedings Based on Newly Discovered and Exceptional Circumstances in the Criminal Procedure of Ukraine - 5. The Signs of Newly Discovered and Exceptional Circumstances in the Criminal Justice System of Ukraine - 6. The System of Newly Discovered and Exceptional Circumstances in the Criminal Procedural Law of Ukraine 7. Conclusions

To cite this article: N Bobechko, A Voinarovych, V Fihurskyi 'Newly Discovered and Exceptional Circumstances in Criminal Procedure of Some European States' 2021 2(10) Access to Justice in Eastern Europe 44-66. D0I: 10.33327/AJEE-184.2-a000059

To link to this article: https://doi.org/10.33327/AJEE-18-4.2-a000059

Submitted on 24 Jan 2021 / Revised 20 Febr 2021 / Approved 30 Apr 2021 / Published online: 03 May 2021 View data

Submit your article to Access to Justice in Eastern Europe http://ajee-journal.com/submissions

\section{ACKOWLEDGMENTS}

Authors would like to express their gratitude to the reviewers for their help and for the English editor, David Phelan.

\section{CONFLICT OF INTEREST}

The authors have declared that no conflict of interest or competing interests exist. Prof. Nazar Bobechko serves as a Member of the Scientific Advisory Board of the Supreme Court. Nevertheless, in this particular research he does not represent any views of this body, and nor is he bound by it.

\section{CONTRIBUTORS}

All the coauthors read, approved the final version and agreed to be accountable for all aspects of this article. 


\title{
NEWLY DISCOVERED AND EXCEPTIONAL CIRCUMSTANCES IN CRIMINAL PROCEDURE OF SOME EUROPEAN STATES
}

\author{
Bobechko Nazar \\ Dr. Sc. (Law), Prof. of the Department of \\ Criminal Procedure and Criminalistics, \\ Ivan Franko National University of Lviv, Ukraine \\ nazar.bobechko@lnu.edu.ua \\ https://orcid.org/0000-0001-9304-3170
}

\section{Voinarovych Alona}

PhD (Law), Assoc. Prof. of the Department of

Criminal Procedure and Criminalistics,

Ivan Franko National University of Lviv, Ukraine

alona.voynarovych@lnu.edu.ua

https://orcid.org/0000-0003-3474-377X

\section{Fihurskyi Volodymyr}

$\mathrm{PhD}$ (Law), Assoc. Prof. of the Department of

Criminal Procedure and Criminalistics,

Ivan Franko National University of Lviv, Ukraine

volodymyr.fihurskyy@lnu.edu.ua

https://orcid.org/0000-0002-5329-8985

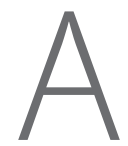

bstract The article analyses the core and contents of the proceedings based on newly discovered or exceptional circumstances (hereinafter - PBNDEC) in the criminal procedure law of Ukraine and other European countries. The authors emphasize that the PBNDEC are not designed to eliminate shortcomings of the pre-trial investigation and the trial in criminal proceedings, providing the reserve function in discovering and correcting court errors, but rather serves its own purpose in the mechanism of legal defence. The order in the criminal procedure activity during this stage is largely determined by the grounds for its implementation - newly discovered or exceptional circumstances (hereinafter - NDEC). The differences between both groups of such circumstances are provided. Procedural features of the PBNDEC, which separate them from the proceedings on appeal and cassation, are singled out. The goals of this stage in the criminal proceedings are formulated, and the significance of this stage has been revealed. The need for improvement in the criminal procedure legislation of Ukraine which regulates the PBNDEC has been justified.

The articles answer the questions of how efficient the regulation of the PBNDEC in the criminal procedure law of Ukraine is: whether the regulation is in agreement with the standards, whether it is established in the criminal procedure law of European countries, whether any doctrine positions regarding the core of such a stage in criminal proceedings require rethinking or additional theoretical justification, and which, of the normative regulations of such form of appeal and review of the court decisions, the principal directions for improvement are.

In order to obtain answers to the aforementioned and other questions, the legal nature and the models of PBNDEC in the criminal legislation of European countries are considered in section two of the article. Section three depicts the procedural specifics of the PBNDEC in the criminal legislation of Ukraine. Section four describes the definition, shows the goals and significance, and introduces the structure of this stage in the criminal proceedings. Section five embraces the 
characteristics of features of NDEC in the criminal legislation of Ukraine. In section six the grounds for the PBNDEC in the criminal procedure law of Ukraine are analysed.

Keywords: restoration of proceedings, newly discovered circumstances, exceptional circumstances, criminal procedure law, Ukraine

\section{INTRODUCTION}

PBNDEC, such as appellate and cassation proceedings, constitute an element of the system that appeals and reviews court decisions in criminal proceedings. Despite the theoretical significance and practical demand, this method of reviewing court decisions is less studied than aforementioned stages of criminal proceedings.

In the doctrine of criminal proceedings and law enforcement activities many issues of this legal institute remain unsolved. Among those there is the legal nature of PBNDEC, its significance in the detection and elimination of judicial errors compared to appellate and cassation proceedings, the orientation of control activities, the correspondence of this criminal procedure mechanisms with the principle of legal certainty, the tasks and significance of PBNDEC, the features and optimal list of NDEC, and the structure of PBNDEC.

Therefore, there has been a need for a complex analysis of problems, connected with the functioning of proceedings based on newly discovered and exceptional circumstances.

This article aims to investigate the theoretical and practical problems of PBNDEC in the criminal proceedings of Ukraine and European countries. To achieve this goal, the following objectives are established: to characterize the essence and the models of PBNDEC in the criminal proceedings of European countries, to reveal the procedural features of PBNDEC in the criminal proceedings of Ukraine, to find out the concepts, tasks, meanings and the structure of PBNDEC in the criminal proceedings of Ukraine, to formulate the features of PBNDEC in the criminal proceedings of Ukraine, and to mention the systems of PBNDEC in the criminal proceedings of Ukraine.

\section{THE ESSENCE AND MODELS OF PROCEEDINGS BASED ON NEWLY DISCOVERED OR EXCEPTIONAL CIRCUMSTANCES IN CRIMINAL PROCEDURE OF SOME EUROPEAN COUNTRIES}

A person found guilty by a court of committing a criminal offence has the right to apply to a court of higher instance to verify the court decision. The procedure for exercising such a right is determined by the law - noted in Art. 2, para.1 of Protocol No. 7 of the Convention for the Protection of Human Rights and Fundamental Freedoms (hereinafter - ECHR) ${ }^{1}$.

In addition to the aforementioned condition, in Art. 4, para. 2, of the Protocol No.7 of the $\mathrm{ECHR}$, it is noted that there is the possibility of reopening a criminal proceeding on the grounds of new facts, which may exert influence on the justice of the court decision ${ }^{2}$.

According to the established case law of the European Court of Human Rights (hereinafter -

$1 \quad$ Protocol No 7 to the Convention for the Protection of Human Rights and Fundamental Freedoms (1984) ETS $117<$ https://www.coe.int/en/web/conventions/full-list/-/conventions/rms/090000168007a082> accessed 20 February 2021. Ibid, 1. 
ECtHR) the procedure of revoking the final court decision requires the existence of previously unknown substantive circumstances of the case. If the procedure is used to eliminate judicial errors, it does not contradict the principle of legal certainty. ${ }^{3}$

The ECtHR developed this legal position in the case Popov v. Moldova No. 2. The opening of proceedings on newly discovered circumstances (hereinafter - NDC) does not contradict the ECHR. However, the legislation must establish the grounds for this, otherwise the abuse of the right to use this procedure cannot be avoided. ${ }^{4}$

The ECtHR allows exceptions to the principle of legal certainty in order to remedy a 'fundamental defect' or a 'miscarriage of justice'. At the same time, in each case it is necessary to assess the justification for deviating from this principle. ${ }^{5}$

This conventional regulation and its interpretation by the ECtHR are due to the fact that sometimes it may happen that injustice, resulting from a court decision, gains legal force, and occurs due to the existence of such circumstances which were unknown to the court at the moment of the making of the decision, and which by themselves, or together with already obtained facts, question the legality, reasonableness and justice of the decision, and as such that decision does not correspond to objective reality. These kinds of circumstances are put by legislators in separate groups of grounds for the review of court decisions, which is explained, first and foremost, by the special ways to certify their existence.

Under such circumstances, there was a need for the existence of yet another form of proceedings for appeal and review of court decisions in the criminal procedure - PBNDEC.

This form of appeal and review of court decisions is a compromise resolution of the conflict of two conceptual approaches - a need to correct a miscarriage of justice that demonstrates the efficiency of the system of criminal justice and a need to provide a stable and unshakable court decision, which gains legal force, thus adhering to the principle of judicial certainty. However, for the criminal procedure legislation, this assertion has a declarative meaning since the legislators unjustifiably put cassation proceedings in one row with an extraordinary form of proceedings on appeal and review of court decisions - proceedings based on NDC, whose task is to check the court decisions that gained legal force. Unfortunately, the position of Ukrainian legislators on this issue is still far from ideal and is evidence of some conceptual defects of judicial reform which is being carried out in Ukraine.

Characterizing the resumption of the proceedings based on NDC (Das Wiederaufnahmeverfahren), German proceduralists note that this institute of criminal procedure serves the material justice, allowing deviation, in exceptional cases, from the interest of the state in ensuring the rule of law. ${ }^{6}$ The legal force of the court decision is inferior if the additionally revealed facts testify to its evident erroneousness. ${ }^{7}$

3 Judgment of the European Court of Human Rights in Pravednaya $v$ Russia, 18 November 2004, paras 27-28 <https://hudoc.echr.coe.int/eng\#\{\%22fulltext\%22:[\%22Pravednaya\%20v.\%20Russia\% 22],\%22documentcollectionid2\%22:[\%22GRANDCHAMBER\%22,\%22CHAMBER\%22],\%22item id\%22:[\%22001-67506\%22]\}> accessed 20 February 2021.

4 Judgment of the European Court of Human Rights in Popov v Moldova, No 2, 6 December 2005, para $46<$ https://hudoc.echr.coe.int/eng\#\{\%22fulltext\%22:[\%22Popov\%20v.\%20Moldova\%22], $\% 22$ documentcollectionid2\%22:[\%22GRANDCHAMBER\%22,\%22CHAMBER\%22],\%22item id\%22:[\%22001-71507\%22]\}> accessed 20 February 2021.

5 Judgment of the European Court of Human Rights in Sutyazhnikv Russia, 23 July 2009, para $35<$ https:// hudoc.echr.coe.int/eng\#\{\%22fulltext\%22:[\%22Sutyazhnik\%20v.\%20Russia\%22],\%22documentcollec tionid2\%22:[\%22GRANDCHAMBER\%22,\%22CHAMBER\%22],\%22itemid\%22:[\%22001-93775\%22]\}> accessed 20 February 2021.

6 K Haller and K Conzen, Das Strafverfahren. 6, neu bearbeitete und erweiterte Auflage (CF Müller 2011), p 513.

7 C Roxin and B Schünemann, Strafverfahrensrecht. 27, neu bearbeitete Auflage. (CH Beck 2012), p 488. 
A similar approach is outlined in the Italian doctrine of criminal procedure - in the proceedings based on NDC (Revisione), the legislators preferred justice over legal certainty. ${ }^{8}$ The proceedings themselves are defined as an exceptional non-voluntary, non-suspensory method of appeal, which makes it possible to overturn court decisions on irrevocable conviction in exceptional cases and can lead to acquittals. ${ }^{9}$

A similar interpretation of resumption of proceedings based on NDC (Wznowienie postepowania karnego) is given by Polish researchers. Along with cassation, the resumption of proceedings is one of the exceptional methods of appeal, which is put by the legislator to the disposition of the participants in the criminal procedure. The possibility of a revision of the court decision, which gains legal force, is an exception to the principle of the steadfastness of decisions that close the criminal proceedings. This gives rise to the exceptional situation, for which the law provides an exhaustive list of grounds, for the reopening of proceedings based on NDC. ${ }^{10}$ The reopening of proceedings is an exceptional procedural institute since its rules are applicable only after the court decision gains legal force and under the condition of the discovery of special circumstances. It entails removing erroneous court decisions from legal circulation. ${ }^{11}$

In the science of criminal proceedings in France, it is claimed that the issues of reviewing of the court decisions in the revision order ( $L a$ révision), analogous to the Ukrainian proceedings based on NDC, the legislators and judges are the real balancers between the guarantee of legal certainty, connected, on one hand, with the property, res judicata, and on the other hand, the urgent need for the detection and correction of judicial errors. ${ }^{12}$

Therefore, PBNDEC purposefully provide unique (extraordinary) forms of appeal and verifications of court decisions. This assertion is also due to the fact that the subject of such proceedings relates to questions of the legality, validity and fairness of court decision, in the first instance of NDECs that had not existed at the time of making this decision but only became known after the decision gained legal force. NDEC cannot be determined in the materials of criminal proceedings since they are not reflected in such materials due to being unknown at the time of trial. Such circumstances are discovered only after the court decision gained legal force; therefore, they need to be researched independently.

The French doctrine of criminal proceedings also mentions that the revision (La révision) has to have a relation to the fact that is contained in the final conviction decision. ${ }^{13}$

Two models of PBNDEC - judicial and mixed - are known in world theory and practice.

The first provides exclusively for court PBNDEC, for which finding out and establishing such circumstances is carried out only by the court from the initiatives of the parties. Such a model has been introduced, for example, in the criminal procedure legislation of Austria, Azerbaijan, Bulgaria, Czech Republic, Italy, France, Georgia, Germany, Kazakhstan, Poland, and Ukraine.

Otherwise, the mixed model consolidates the investigative and prosecutorial investigation or verification when discovering NDEC, exerting influence on the justice of the court decision and ensuring that further direction of criminal proceedings is carried out in court. Such a

$8 \quad$ P Tonini, Manuale di procedura penale. Quindicesima edizione (Giuffrè Editore 2014), p 961.

9 G Spangher, 'Impugnazioni straordinarie: aspetti sistematici di una categoria allargata' in Paola Corvi (ed), Le impugnazioni straordinarie nel processo penale (Giappichelli 2016), p 5.

10 A Kołodziejczyk, 'Wznowienie postępowania karnego na podstawie art 540 a pkt 1 kpk - zagadnienia wybrane' (2010) 14 Studia Iuridica Lublinensia 161.

11 M Mrowicki, Wznowienie postępowania karnego na podstawie rozstrzygnięcia Europejskiego Trybunatu Praw Człowieka (Rzecznik Praw Obywatelskich 2020), p 16-17.

12 D Goetz, La révision en matère pénale (Université de Strasbourg 2015), p 20.

13 D Goetz (n 12) 17. 
model defines two subjects of application of criminal procedure norms in the framework of PBNDEC - prosecutor and court. A special feature of the mixed model is also the fact that no other proceedings contain so many elements of pre-trial and trial stages of criminal proceedings. This is criminal proceedings in miniature. Such a model has been introduced in the Criminal Procedure Code (hereinafter - CrPC) of Belarus, Kyrgyzstan, Moldova, Russia, and Uzbekistan.

\section{PROCEDURAL FEATURES OF PROCEEDINGS BASED ON NEWLY DISCOVERED OR EXCEPTIONAL CIRCUMSTANCES IN THE CRIMINAL JUSTICE SYSTEM OF UKRAINE}

It is worth mentioning that in 2017 the Ukrainian legislator supplemented the criminal procedure law with the new institute, 'of exceptional circumstances'. In fact, two groups of circumstances that in the past were called 'newly discovered', [established by the Constitutional Court of Ukraine (hereinafter - CCU), the unconstitutionality of laws, other legal acts or their specific paragraphs, used by court for the resolution of the case; and establishing the guilt of a judge in committing a crime or an abuse of power by a detective, prosecutor, investigating judge or court during the criminal proceedings as a result of which the court decision has been made] received the name 'exceptional'. Apart from that, exceptional circumstances also include a determination by an international judicial institution, whose jurisdiction is recognized by Ukraine, of a violation by Ukraine of international obligations during the resolution of the case in court. ${ }^{14}$

A comparison of these circumstances with the corresponding circumstances provided for in the criminal procedure law of European countries provides grounds for making a conclusion about their similarity. However, in order to comply with the terminology, provided for by the CrPC of Ukraine regarding the Ukrainian criminal procedure legislation, the authors will refer to the PBNDEC.

PBNDEC are an integral part of criminal justice. Therefore, during the implementation of its norms, the principles of criminal procedure apply, which characterize how appeals are structured and how court decisions are verified. Apart from such structured forms, the PBNDEC are built based on provisions that differentiate this stage of criminal procedure activity from other stages of criminal procedure, that determine its place and role in the system of the types of proceedings on appeals and the verification of court decisions. In this, we are dealing with the procedural features of PBNDEC.

The value of procedural features of PBNDEC is in the facts that: a) they characterize the essence of the proceedings and reveal the purpose of this form of proceedings on appeal and the verification of court decisions; b) they are the fundamental rules, on the basis of which the PBNDEC are constructed; c) they make it possible to evaluate the efficiency of such controlling proceedings; d) they incorporate theoretical approaches to the construction of the verification stages of the criminal proceedings; e) they are the basis for directing the practical aspects for the courts, which are authorized to carry out PBNDEC.

The category 'procedural features of PBNDEC' means that there exist such provisions that substantially distinguish the proceedings regulated in chapter 34 of $\mathrm{CrPC}$ of Ukraine from the other proceedings on appeal and the verification of court decisions (appeal and cassation). ${ }^{15}$

14 Code of Ukraine of 13 April 2012 No 4651-VI 'Criminal Procedure Code of Ukraine' (as amended on 12 December 2020), chapter 34 <https://zakon.rada.gov.ua/laws/show/4651-17\#Text> accessed 20 February 2021.

15 Code of Ukraine (n 14). 
In the opinion of some French authors, the uniqueness of revision (La révision) is revealed both in its purpose, that is to correct a miscarriage of justice, and in its consequences that comprise the cancellation of the final court decision. Apart from that, since this is the extraordinary measure of legal protection, directed against the decision with the property res judicata, its implementation remains suspended in the cases of proceedings resumption, provided by the law. To conclude, the explanation of the specifics of court decisions on the review in revision order is in small number. Among 150 petitions on the review, submitted annually, only a few result in the cancellation of the conviction. ${ }^{16}$

The procedural features of PBNDEC in criminal procedure law of Ukraine is seen in the following.

Firstly, their verification subjects are the court decisions that gained the legal power, and which are put to execution or even partially or fully executed. At first glance, such a mechanism contradicts the principle of legal certainty (res judicata pro veritate habetur). The ECtHR emphasizes that, in accordance with the principle of legal certainty, a party is not entitled to insist on a review of a final judgment solely for the purpose of a retrial and a new judgment. Courts of higher instance should use their powers to correct judicial errors, not to review cases. Exceptions to this rule may be due to circumstances that are significant and irrefutable. ${ }^{17}$ However, the purpose of PBNDEC is not for the revision of court decisions - a reconsideration of the criminal proceedings on the merits and adoption of the new decision, for example, for the actions requalification, mitigation or the intensification of punishment - but rather the correction of the specific judicial errors.

Secondly, such proceedings are related to each major or final court decision that gained the legal force, apart from the decisions of investigating judges. PBNDEC verify the major court decisions and the decisions, in which the issues are solved during the actual execution of the court decisions under the condition that they gained the legal force.

In other words, as a result of NDEC the following might be verified: convictions and acquittals, decisions on closing criminal proceedings, decisions on closing criminal proceedings and releasing a person from criminal liability, decisions on applying the mandatory measures of an educational or medical nature, decisions, which resolve the issues, connected with the execution of court decisions, as well as sentences and decisions of appeal courts, resolutions of the cassation courts regarding the aforementioned court decisions;

Thirdly, the presence of specific grounds for the proceedings - NDEC. NDEC do not compete with the grounds for appealing and verifying court decisions in the orders of appeal and cassation; on the contrary, they directly exclude such grounds. This is also confirmed by the exclusion of PBNDEC in a separate form of proceedings for appealing and verifying court decisions. If the court decisions have not yet gained legal power, then no extraordinary procedural methods are required for the determination and establishment of the NDEC since the decision is verified from of the perspective of all the grounds for the cancellation or change of court decisions on appeal.

On the other hand, NDC as one of the groups of grounds for verifying court decisions in criminal proceedings, being different from all other grounds for the cancellation or change

16 D Goetz (n 12) 14-15, 20-21.

17 Judgment of the European Court of Human Rights in Ryabykh $v$ Russia, 24 July 2003, para $52<$ https:// hudoc.echr.coe.int/rus\#\{\%22fulltext\%22:[\%22Ryabykh\%20v.\%20Russia\%22],\%22documentcollectio nid2\%22:[\%22GRANDCHAMBER\%22,\%22CHAMBER\%22],\%22itemid\%22:[\%22001-61261\%22]\}>accessed 20 February 2021; Judgment of the European Court of Human Rights in Ponomaryov $v$ Ukraine, 3 April 2008, para $40<$ https://hudoc.echr.coe.int/rus\#\{\%22fulltext $\% 22:[\% 22$ Ponomaryov\%20 v.\%20Ukraine\%22],\%22documentcollectionid2\%22:[\%22GRANDCHAMBER\%22,\%22CHAMBER\% 22],\%22itemid\%22:[\%22001-85683\%22]\}> accessed 20 February 2021. 
of court decisions in their form, are similar to those from the viewpoint of content. Indeed, if the sentence is based on knowingly false testimony of a witness and if the fact that the testimony is false is found out after the decision gained legal power (item 1, pt. 2, Art. 459 of the CrPC of Ukraine), then the court conclusions of the first instance might be inconsistent with the actual circumstances of the criminal proceedings (item 2, p. 1, Art. 409, Art. 411 of the $\mathrm{CrPC}$ of Ukraine). If other circumstances are revealed, which by themselves or together with the circumstances established beforehand, prove illegality, unfoundedness and unfairness of the court decision' and were not known by the court when such a decision was made (item 4, p. 2, Art. 459 of the CrPC of Ukraine), then the trial might be incomplete (item 1, p. 1, Art. 409 of the CrPC of Ukraine). ${ }^{18}$

At the same time, according to p. 5, Art. 459 of the CrPC of Ukraine a revision of court decisions based on NDC in the case when new laws or other legal acts are adopted, which cancel the laws that acted when the decision had been made, is prohibited. ${ }^{19}$ Therefore, a change of legislation cannot be a ground to carry out proceedings based on NDC.

The extraordinary nature of the proceedings based on NDC is due to the existence of special grounds for the verification of court decisions that gained legal power as a fact. Moreover, establishing the circumstances, which were unknown to the court when making the decision and which by themselves or together with already reliably established facts put in doubt the justice of such a decision, in comparison with grounds on appeal or cassation is quite rare. Inconsistency with legal regulations and (or) judicial enforcement with the norms of the Constitution of Ukraine or ECHR is also not common;

Fourthly, verification of the court decision based on NDEC at the same instance (first, appeal, cassation), which was first to commit an error as a result of being unaware of the existence of such circumstances. In Art. 460, p. 1, Art. 463 of the CrPC of Ukraine it is noted about the possibility of verification of the court decision due to NDEC only by the court instances. According to parts 1-3, Art. 33 of the CrPC of Ukraine three instances are provided: first, appeal and cassation ${ }^{20}$.

At the same time, p. 4, Art. 33 of the CrPC of Ukraine establishes that criminal proceedings based on NDC are carried out by a court that made the decision, which is under revision. Instead, according to p. 5, Art. 33 of the same article, the criminal proceedings based on NDC are carried out by a court that made a decision, which is under revision, on the grounds, established by items 1, 3, p. 3, Art. 459 of the CrPC of Ukraine, but are carried out by the Grand Chamber of The Supreme Court on the grounds established by item 2, p. 3, Art. 459 of the CrPC of Ukraine ${ }^{21}$.

Taking into account the aforementioned provisions of the criminal procedure legislation of Ukraine, under 'court that made a decision, which is under revision', in the case of the PBNDEC, one should understand the court of the first, appeal or cassation instance.

Fifthly, the possibility of opening the PBNDEC regarding the person, for which the sentence has been made, which gained the legal power on the same accusation or the court decision, the resolution of the coroner, the investigator, the detective of the National Anti-Corruption Bureau of Ukraine (hereinafter - NABU), the prosecutor on the closure of the criminal proceedings on the same ground. In this case the procedural status of such a person during the proceedings based on NDC remains unchanged. The convict is considered convicted, the acquitted is acquitted.

\begin{tabular}{ll}
\hline 18 & Code of Ukraine (n 14). \\
19 & ibid, 14. \\
20 & ibid, 14. \\
21 & Code of Ukraine (n 14).
\end{tabular}


Sixth, there is no such instance in criminal proceedings, of the decision being considered final and could not have been verified from the point of view of any NDEC;

Seventhly, fixing the specific methods of establishing NDEC: decision-making and gaining the legal force by the court of first instance conviction regarding the actions, established in item 1, p. 2, item 3, p. 3, Art. 459 of CrPC of Ukraine; the court decision and gaining the legal force by the court decision on the closure of criminal proceedings and release from criminal liability, the court decision on the application of coercive measures of an educational or medical nature in case of the impossibility of conviction with respect to the actions, provided in item 1, p. 2, item 3, p. 3, Art. 459 of CrPC of Ukraine and the circumstances, established in item 4, p. 2, Art. 459 of the CrPC of Ukraine; the ruling, making the decision by the coroner, the NABU detective, the investigator, the prosecutor on the closure of criminal proceedings in case of the impossibility of conviction with respect to the actions, provided in item $1, \mathrm{p}$. 2, item 3, p. 3, Art. 459 of CrPC of Ukraine and the circumstances, established in item 4, p. 2, Art. 459 of the CrPC of Ukraine; decision-making and gaining the legal force by the court of a higher instance with respect to the circumstances, provided in item 3, p. 2, Art. 459 of the CrPC of Ukraine; publication of the decision of the CCU regarding the circumstances, provided in item 1, p. 3, Art. 459 of the CrPC of Ukraine; the decision and gaining the legal force of the court of higher instance regarding the circumstances, established in item 3, p. 2, Art. 459 of the CrPC of Ukraine; the acquisition of status as final by the decision of the ECtHR regarding the circumstance, provided in item 2, p. 3, Art. 459 of the CrPC of Ukraine $^{22}$.

Eighthly, attribution to the discretionary powers of court the research of the evidence regarding circumstances, established in the court decision, which is being verified. According to p. 4, Art. 466 of the CrPC of Ukraine, the court has the power not to research the evidence regarding the circumstances, established in the court decision that is being verified on the basis of NDEC, if they are not disputed ${ }^{23}$.

This provision is quite controversial since from the point of view of NDEC such evidence might turn out to be unreliable. Evidence, on which the court decision is based, is interconnected, and therefore the court has to check the influence of the newly discovered or exceptional circumstance on each piece of evidence separately as well as on the evidence in its entirety. Apart from that, the court can make a decision that is described in p. 4, Art. 466 of the CrPC of Ukraine only with the consent of all the parties in the proceedings ${ }^{24}$.

Ninthly, the impossibility to change or cancel the court decision, that was being verified with respect to NDEC, with the closure of the proceedings. According to p. 1, Art. 467 of the CrPC of Ukraine, the court has the power to overturn a sentence or decision and decide on a new sentence or decision or leave the application for review of the court decision unsatisfied. When making a new court decision the court uses the powers of the court of a corresponding instance. The revision of the court decision on NDEC by the Supreme Court might also lead to the cancellation of the court decision (court decisions) fully or partially and send the case for new consideration to the court of the first instance or the Court of Appeal. ${ }^{25}$

The main argument in the prohibition of making changes to the court decision or its cancellation followed by the closure of criminal PBNDEC is the fact that they were not the subject of consideration by the courts of the first instance or by the Courts of Appeal. However, such an argument does not seem to be convincing. The Court of Appeal in some 
cases has the power to change or cancel the court decision on the grounds of new evidence, which was not the subject of considerations in court. Then why should the competent court be deprived of a possibility to make changes in a court decision and to cancel the court decision with the subsequent closure of criminal proceedings based on newly discovered or exceptional evidence if the information about the evidence, which confirms the presence of such circumstances, is obtained in a much more reliable way, and the proceedings in court are carried out according to identical rules? The current legislative regulation of this issue is far from being optimal.

\section{THE CONCEPT, TASKS, SIGNIFICANCE AND THE STRUCTURE OF PROCEEDINGS BASED ON NEWLY DISCOVERED AND EXCEPTIONAL CIRCUMSTANCES IN CRIMINAL PROCEDURE OF UKRAINE}

The PBNDEC is the stage of criminal proceedings which regulates the actions of the participants of court proceedings with regard to the appeal of final decisions of the courts of the first instance, courts on appeal and courts on cassation that gained legal force as well as the specific courts established by the criminal procedure law of the materials in the criminal proceedings from the point of view of well-established circumstances, which were unknown to the court during the court proceedings, or those circumstances that appeared after the decision was made and influenced, or could have influenced the legality, reasonableness and justice of such a decision.

The goals of the proceedings based on newly discovered and exceptional circumstances are the following: a) judicial control of the courts of first instance, courts on appeal and courts on cassation, from the point of view of facts (error facti) and in specific cases from the point of view of the correspondence of legislative regulation and judicial enforcement (error iuris) with the Constitution of Ukraine, the ECHR and in the case when the existence of NDEC is established, the bringing of the appealed court decision in keeping with the other court decision of the general jurisdiction, the decision of the CCU, the ECtHR or the final act of the pre-trial investigation body; b) defense of judicial court decisions that gained the legal force from their unreasonable, unjustified change or cancellation.

In the French doctrine of criminal proceedings, it is emphasized that it is impossible to use the mechanism of review (La révision) under the condition of the existence of legal grounds for the correction of court (judicial) errors along with the other forms of appeal and review of court decisions. ${ }^{26}$ The review may be used only in the cases when all traditional instruments of legal defense are completely closed. ${ }^{27}$

Austrian processualists categorically state that the resumption of a criminal case on the ground of the fact that the court decision was made when the procedural or material errors existed or that the evaluation of the evidence is false as well as that the sentence was too lenient or too severe, is impossible. ${ }^{28}$

A similar point of view is also justified in Slovak literature on criminal procedure legislation. The aim of a resumption of proceedings based on NDC is not the verification of legality and the validity of the court decision and the correct application of the criminal procedure

26 B Bouloc, Procédure pénale, 24-e édition (Dalloz 2014), p 1024; J Pradel, Procédure pénale, 17-e édition (Éditions Cujas 2013), p 900-901; ML Rassat, Procédure pénale, 2-e édition (Ellipses Édition Marketing SA 2013) p 737.

27 D Goetz (n 12, 16).

28 EE Fabrizy, Kurzkommentar StPO 1975, 11 neu bearbeitete Auflage (Manz 2011), p 771. 
activity that was performed before the decision. In such proceedings the court may not investigate the factual grounds of the court decision that resulted from the preliminary trial or verify whether the order is obeyed by court and by participants during the preliminary trial. Therefore, in the proceedings based on NDC, the approach of review is not applied. ${ }^{29}$

Summing up the above positions, it is worth pointing out that the mistakes in factual determination of the case, an erroneous assessment of the evidence, a misapplication of criminal law and a serious breach of the requirements of the law of criminal procedure, the unfair application of non-custodial penalties cannot be considered the grounds for proceeding, based on NDEC.

Thus, the meaning of PBNDEC lies in the fact that such a form of appeal and review of court decisions is an additional guarantee of justice, a protection of rights and legal interests of the participants of judicial proceedings, the restoration of their rights and freedoms as compared to the main ones - appellate and cassation proceedings. PBNDEC have considerable potential, however, the practice of applying their norms is relatively rare as compared to the appellate and cassation proceedings.

The analysis of the provisions of chapter 34 of the CrPC of Ukraine allows us to state that the PBNDEC consist of three parts: 1) lodging the application for a review of the court decision based on NDEC and the verification of this request on the subject of correspondence to the formal requirements; 2) preparation to the review of the court decision based on NDEC (iudicium rescindens); 3) verification of the court decision based on NDEC (iudicium rescisorium). ${ }^{30}$

\section{THE SIGNS OF NEWLY DISCOVERED AND EXCEPTIONAL CIRCUMSTANCES IN THE CRIMINAL JUSTICE SYSTEM OF UKRAINE}

The central inception of any proceeding on appeal and a verification of the court decision is its grounds. The court decisions, in particular the court decisions which gained legal force, may not be verified from the point of view of far-fetched, abstract, ambiguous criteria. The effectiveness of the PBNDEC largely depends on the regulatory aspects of such grounds.

As mentioned in the previous section, the special nature of the PBNDEC lies in the existence of the special grounds for the verification of the court decisions which gained legal force.

Newly discovered and exceptional circumstances differ from the grounds for the change or cancellation of the court decisions in the appeal and cassation orders. Let us now establish the features of such circumstances.

Newly discovered and exceptional circumstances have the following features:

1) they have to objectively exist at the moment when the court decision is made or they have to appear after the court decision is made. However, such facts were not reflected in the materials of the criminal proceedings as a result of intentional false testimonies of the participants of court proceedings, intentional false translations, intentional false conclusions of experts, the falsification of evidence or documents, or as a result of other reasons.

Instead, the establishment by the CCU of the unconstitutionality of the law or other

29 'Trestné právo procesné' in Jaroslav Ivor (ed), Druhé, doplnené a prepracované vydanie (Iura Edition 2010); 'Trestné právo procesné. V̌̌eobecná a osobitná čast' in Josef Čentéš (ed) 2 vydanie (Heuréka 2012), p 659. 
legislative act or their separate provisions, applied by the court during the resolution of the case (item 1, p. 3, Art. 459 of the CrPC of Ukraine) as well as the establishment by the ECtHR of the violation by Ukraine of international obligations during the resolution of the case in court (item 2, p. 3, Art. 459 of the CrPC of Ukraine) is possible only after the court decision is $\operatorname{made}^{31}$;

2) they did not exist or were not known to the court during the criminal proceedings or verification of the court decision in the order of appeal or cassation that results in the impossibility of taking them into account. A preliminary, unknown circumstance to the court is a circumstance that could not have been discovered during the trial and could not have been accounted for when the court decision was made.

However, criminal procedure law (item 4, p. 2, Art. 462 of the CrPC of Ukraine) requires that such circumstances were unknown also to the parties of the criminal proceedings (noviter reperta). Therefore, in case of initiating PBNDEC, the participant in the court proceedings has to prove that certain circumstances that were unknown to the court were unknown also to him. In our opinion, such an approach of the legislators is erroneous. Firstly, it contradicts the provisions of item 4, p. 2, Art. 459, item 1, Art. 463 of the CrPC of Ukraine, which establish that the NDEC must be unknown only to the court ${ }^{32}$. Moreover, in national as well as foreign procedure theory the separate feature of NDC is considered to be axiomatic.

On the term (new) facts, the Federal Constitutional Court of Germany states: facts shall be understood as existing, identifiable occurrences or circumstances which belong to the past or the present. Whether a fact is new or not shall be judged solely according to whether or not the court has already utilized it. Therefore, in principle, new is everything which the court has not taken as a basis for forming its opinion, even if it could have taken such as a basis. Therefore, in order to assess the question of whether a fact is new, one must refer to the time of the decision, meaning the conclusion of deliberation in cases of convictions. Evidence discussed in the main proceedings may also be new if the court has not taken such as the basis for its decision ${ }^{33}$.

The analyzed feature of NDEC is not related only to the criminal abuse by the courts during criminal proceedings (item 3, p. 3, Art. 459 of the CrPC of Ukraine) ${ }^{34}$.

However, the discovery of the evidence that confirms or contradicts facts researched in the court after the adjudication may not be grounds for the review of the court decision based on NDEC. New evidence may be grounds for the review of the court decision in the appeal order but not based on NDEC;

3 ) they play a significant role in criminal proceedings. Since some circumstances may remain unknown because of a lack of information about them in the materials of the criminal proceedings and as a result may remain unresearched in the court hearing, the evidence, which was collected during the criminal procedure activity, has led to the seemingly correct but actually wrong decision in its core. In other words, NDEC allow us to make other conclusions regarding the guilt or innocence of a person or the degree of the public danger of criminal liability than the ones provided by the court when making the decision without such circumstances.

The NDEC in their nature affect or may affect the legality, reasonableness and justice of the court decision that gained the legal force. Therefore, they by themselves or together with

\footnotetext{
31 Code of Ukraine c

32 Code of Ukraine (n 14).

33 M Lindemann and F Lienau, 'Mechanisms for Correcting Judicial Errors in Germany' (2020) 4 (incomplete) Erasmus Law Review1.

34 Code of Ukraine (n 14).
} 
already established facts question the justice of the court decision as such that does not correspond to the objective reality.

4) they exist in organic unity with the elements of the subject of proof in the criminal proceedings or establish correspondence to the legal regulations and (or) law enforcement activities with the Constitution of Ukraine, ECHR. The falsification of the specific piece of evidence established by the court decision that gained the legal force, may be the ground for the review of the court decision based on newly discovered evidence only in the case when such a court decision is based on this piece of evidence. Since the evaluation of the evidence is based on the comprehensive, complete and impartial research of all the circumstances in the criminal proceedings, the falsification of at least one piece of evidence that does not directly point to the guilt or innocence of a person in the criminal offence, incriminated to him or to the degree of public danger of a person, may affect the court conclusions and lead to the making of an unjust court decision.

Such exceptional circumstances as the establishment by the CCU of the unconstitutionality of the law, other legal act or its separate provision applied by the court during the resolution of the case (item 1, p. 3, Art. 459 of the CrPC of Ukraine) and the establishment by the ECtHR of the violation by Ukraine of its international obligations during the court resolution of the case (item 2, p. 3, Art. 459 of the CrPC of Ukraine), unlike the groups of the circumstances provided in p. 2 and item 3, p. 2, Art. 459 of the CrPC of Ukraine ${ }^{35}$ do not belong to the subject of the proof in the criminal proceedings since they did not exist at the time of the court proceedings and at the moment of adjudication. They also do not point out criminal abuse by subjects in the criminal proceedings, but to the inconsistency of the procedure of court proceedings, substantive and legal grounds of court decisions with the Constitution of Ukraine, the ECHR;

5) they may be discovered only after the court decision gained the legal force. Before the court decisions gained legal force the circumstances provided in the items 2, 3 Art. 459 of the $\mathrm{CrPC}$ of Ukraine are seen as part of the circumstances provided in Art. 409 of the CrPC of Ukraine for the cancellation or change of the sentences, rulings and resolutions on appeal ${ }^{36}$;

6) they have to be established by the conviction that gained the legal force, by the decision of the coroner, the investigator, the NABU detective, the prosecutor on the closure of the criminal proceedings, the court decision on the closure of the criminal proceedings and release from criminal liability, the court decision on application of coercive measures of an educational or medical nature or the decision of the CCU, the ECtHR. The specific order of discovery and establishment of the NDC is necessary since the materials that are already part of criminal proceedings are not sufficient to answer the question of justice of the court decision.

Therefore, the grounds for the PBNDEC are established by the conviction that gained the legal force, by the decision of the coroner, by the court decision on the closure of criminal proceedings and release from criminal liability, a court decision on the application of coercive measures of an educational or medical nature or the decision by the CCU, the ECtHR, sufficient pieces of information that point to the existence of any circumstances, provided in pp. 2, 3, Art. 459 of the CrPC of Ukraine that existed during the court proceedings and were unknown to the court or appeared after the adjudication and are in organic unity with the elements of the subject of proof and establish the inconsistency of legislative regulations and (or) law enforcement activities with the Constitution of Ukraine, the ECHR and result or may result in illegality, unfoundedness and unfairness of the disputed court decision. 


\section{THE SYSTEM OF NEWLY DISCOVERED AND EXCEPTIONAL CIRCUMSTANCES IN CRIMINAL PROCEDURAL LAW OF UKRAINE}

The system of grounds for the proceedings based on NDC is provided in p. 2, Art. 459 of the CrPC of Ukraine: 1) the artificial creation or falsification of evidence, incorrect translation of the conclusion and explanations of the expert, knowingly false testimonies of the witness, victim, suspect, accused, on the grounds of which the sentence is based; 2) cancellation of the court decision, which became the grounds for the sentence or decision that has to be revised; 3) other circumstances that were unknown to the court at the moment of the trial during the decision-making and which by themselves or together with the circumstances established beforehand prove the incorrectness of the sentence or the decision that has to be revised ${ }^{37}$.

Let us carry out an analysis of the legislative groups of NDC.

Artificial creation or falsification of evidence, incorrect translation of the conclusion and explanations of the expert, knowingly false testimonies of the witness, victim, suspect, accused, on the grounds of which the sentence is based (item 1 p. 2, Art. 459 of the CrPC of Ukraine $)^{38}$ - propter crimina or propter falsa. In the context of item 1, p. 2, Art. 459 of the CrPC of Ukraine under the artificial creation or falsification of evidence one means the falsification of physical evidence and documents, in particular the protocols of the procedural actions.

The falsification of physical evidence can consist of the deliberate artificial creation of the things in order to provide them with the properties of physical evidence, of the deliberate representation of the things which in fact are not physical evidence, or of the artificial creation of the fact of detection of the things in a certain place.

The falsification of documents can be manifested in the deliberate entering of data which are fully or partially false, in the deliberate creation of documents where the data are fully or partially false, in the forgery of documents by changing the text in them (cleaning, etching, washing, adding, etc.) or in changing their separate fragments (pasting photos, affixing a fake stamp, etc.).

Item 1, p. 2, Art. 459 of the CrPC of Ukraine amongst the grounds for the proceedings based on NDC mentions also incorrect translation of the conclusion and explanations of the expert ${ }^{39}$. However, from the point of view of criminal legislation, only the deliberate conclusion of the expert is recognized as a crime against justice (Art. 384 of the Criminal Code (hereinafter - CrC) of Ukraine) $)^{40}$. The expert is not criminally liable for providing a knowingly false explanation. Therefore, the requirement to establish in the sentence the fact of knowingly false explanation by the expert cannot be implemented.

The incorrect translation can also be a result either of a conscientious mistake of the translator or a deliberate distortion of information. Item 1, p. 2, Art. 459 of the CrPC of Ukraine contains an imperative norm, according to which only a deliberately false translation is established as a sentence that gained legal force ${ }^{41}$. And so, this is why criminal liability arises in accordance with Art. 384 of the CrC of Ukraine ${ }^{42}$.

\footnotetext{
37 Code of Ukraine (n 14).

38 ibid, 14.

39 ibid (n 14).

40 Code of Ukraine of 5 April 2001 No 2341-III ‘Criminal Code of Ukraine' (as amended of 4 December 2020) <https://zakon.rada.gov.ua/laws/show/2341-14\#Text> accessed 20 February 2021.

41 Code of Ukraine (n 14).

42 Code of Ukraine (n 40).
} 
A knowingly wrong conclusion by the expert can mean the deliberate distortion of the essence of the experiments, if the conclusions arrived at obviously contradict the facts that had been established earlier during the expert research, or if there is a deliberate denial of the established facts, or a deliberately incorrect evaluation of such facts, or a deliberate hiding of information about facts. Meanwhile, a conscientious mistake by the expert or the presentation of contradictory scientific conclusions does not result in a criminal liability according to Art. 384 of the CC of Ukraine ${ }^{43}$.

Knowingly incorrect translation can cause a deliberate distortion of the content of documents, testimonies, explanations, replicas, questions and answers of the subjects in criminal proceedings, or a deliberate omission of separate words and phrases which distort their general content, or the deliberate concealment of certain fragments during the translation from one language to the other in order to achieve the desired results for the interested persons. If the translator commits such actions, the criminal liability follows according to Art. 384 of the CrC of Ukraine. ${ }^{44}$ At the same time, the incompetence of the translator, which led to mistakes in the translation, gives no indication about knowingly translating incorrectly and excludes the application of criminal liability.

In item 1, p. 2, Art. 459 of the CrPC of Ukraine amongst the grounds for the proceedings based on NDC the giving knowingly of false testimony by the witness, victim, suspect, or accused are mentioned. ${ }^{45}$ Awareness of the false testimonies can be seen in the deliberate hiding of information about the circumstances which took place in reality, in the deliberate distortion of such information during the notification of the coroner, investigator, NABU detective, prosecutor, investigating judge or court, or in the deliberate notification about such circumstances that have not occurred. Providing knowingly false testimonies can happen during the interrogation, upon presentation for identification, or during the investigative experiment. One can talk about the false testimonies only in the case, when the circumstances, within which the knowingly false information was obtained, are valuable for the criminal proceedings.

As mentioned above, as the grounds for the review of court decisions is based on NDC, the legislator recognizes the knowingly false testimonies of the suspect and the accused. However, taking into account the special procedural status, the aforementioned participants of the court proceedings are not under criminal liability for providing knowingly false testimonies. Therefore, if the suspect or the accused slanders other accomplices, with which the criminal offence was committed, then that suspect (or the accused) would not be under criminal liability for providing the knowingly false testimony. However, the suspect and the accused can slander other persons in committing the criminal offence who are innocent or guilty to a lesser degree. In such cases the court decision is due to be reviewed according to item 4, p. 2, Art. 459 of the CrPC of Ukraine. ${ }^{46}$

The cancellation of the court decision that has become a ground for the sentence or decision, which is due to be reviewed (item 3, p. 2, Art. 459 of the CrPC of Ukraine). ${ }^{47}$ Such a circumstance is connected with the prejudicial nature of court decisions. However, its implementation is not a Ukrainian consideration. Such a circumstance is known to the criminal procedure legislation of other countries.

Indeed, according to item 4 para 359 of the CrPC of the Federal Republic of Germany (Strafprozessordnung) one of the grounds for the resumption of criminal proceedings based

\begin{tabular}{ll}
\hline 43 & ibid (n 40). \\
44 & Code of Ukraine (n 40). \\
45 & Code of Ukraine (n 14). \\
46 & ibid (n 14). \\
47 & Code of Ukraine (n 14).
\end{tabular}


on NDC is the cancellation of a civil law decision upon which the sentence is based, by the other court decision that gained legal force. ${ }^{48}$ In the prevailing opinion, the scope of the application of this ground for a retrial should cover not just the civil judgements explicitly mentioned in the norm, but also judgements under labour, social, administrative and financial law ${ }^{49}$.

The ground of similar content is also provided for in item 'b', Art. 630 of the CrPC of the Italian Republic (Codice di procedura penale). ${ }^{50}$

Similar ground is known to the CrPC of the Republic of Estonia (Kriminaalmenetluse seadustik). Indeed, according to item 4, Art. 366 of this codified act, the ground for the resumption of the proceedings based on NDC in the criminal case is the cancellation of the other sentence or court decision that became a ground for a sentence or court decision in the criminal case, in which the proceedings is resumed, if it could lead to an acquittal in the criminal case or to improving the situation of the convict. ${ }^{51}$

At the same time, the cancellation of the court decision by itself that resulted in a sentence or decision, is not likely to be a ground for the revision of court decisions based on NDC. This is possible, when the cancellation of the court decision is carried out in terms of such circumstances being established correctly, which made a ground for the sentence (court order) and under the condition that the use of such circumstances affected justice of such sentence (court order). In the same way it is not clear why in item 3, p. 2, Art. 459 of the $\mathrm{CrPC}$ of Ukraine only cancellation is mentioned and not the change of the court decision. Obviously, a change in the court decision may also affect the actual circumstances of the criminal proceedings. Even more surprising is the requirement of the legislation concerning how such circumstances are established by the sentence of the court, which gained the legal force, and in the case of the making of the decision being impossible, then the confirmation of such circumstances by the investigation materials (item 3, Art. 459 of the CrPC of Ukraine). Since in item 3, p. 2, Art. 459 of the CrPC of Ukraine, the criminal offence is not discussed ${ }^{52}$, therefore, the regulation of the analysed ground needs to be improved.

All the other circumstances, which were unknown to the court at the time of the trial when making a court decision and which by themselves or together with other circumstances discovered earlier, prove the incorrectness of the sentence or decision that has to be reviewed (item 4, p. 2, Art. 459 of the CrPC of Ukraine) $)^{53}$ - propter noviter producta. Criminal procedure law of Ukraine does not provide an exhaustive list of NDC. This is explained by the variety and unpredictability of situations in life which may occur. Only the instruction to all the other circumstances - which were unknown to the court at the time of making a court decision and which by themselves or together with the other circumstances discovered earlier prove the injustice of such a decision-is provided.

There are four groups of such circumstances.

48 Law of the Federal Republic of Germany of 1 February 1877 'German Code of Criminal Procedure' (as amended of 3 December 2020) < https://www.gesetze-im-internet.de/englisch_stpo/englisch_stpo. html\#p2198> accessed 20 February 2021.

49 M Lindemann and F Lienau (n 33) 6-7.

50 Code of Criminal Procedure of Italy of 22 September 1988 No 477 'Codici di procedura penale' (as amended of 25 June 2020) <https://www.brocardi.it/codice-di-procedura-penale/libro-nono/titolo-iv/ art630.html > accessed 20 February 2021.

51 Law of the Republic of Estonia of 12 February 2003 'Code of Criminal Procedure of the Republic of Estonia’ (as amended of 26 September 2013) <https://www.riigiteataja.ee/en/eli/530102013093/ consolide> accessed 20 February 2021.

52 Code of Ukraine (n 14).

53 ibid (n 14). 
First group. Circumstances that prove that the conviction is false. These include information on the conviction for the murder of a person who afterwards turns out to be alive, the circumstances that indicate the insanity of the person who is serving a sentence, and a statement with the confession of a person who has not been prosecuted but who confesses to have committed the criminal offence that another person has been convicted for.

Second group. Circumstances that prove that the convict committed a criminal offence of a lesser degree. For instance, an excessive severity of punishment which ensued from the conscientious mistake of witnesses, because the court did not have reliable information about the actions of the convict at the moment when the criminal offence was committed. Erroneous expert opinion in terms of establishing the amount of stolen property, when a repeated forensic accounting examination established that the amount incriminated to the convict is unreasonable, also belongs to this group of circumstances.

Third group. Circumstances that prove that the convict committed a criminal offence of a higher degree. They can be confirmed by the following information: the discovery of new accomplices to the criminal offence not earlier known about, the discovery of new episodes of criminal activity, the information about the fact that the person having been an adult pretended to be a minor, or an erroneous conclusion of a forensic psychiatric examination of insanity.

Fourth group. Circumstances that prove the erroneous justification or closure of criminal proceedings by the court. For example, the change of testimony by one of the convicts with respect to the other about the involvement of the latter in the commission of a criminal offence.

The implementation, in the 1990s, of the new, not previously known to the domestic legislation system, institute of constitutional jurisdiction and the joining of Ukraine to the system of the protection of human rights and freedoms, the implementation in the national legislation of the provisions of the ECHR, together with the recognition of the ECtHR, forced the legislator to expand the list of the grounds for the resumption of proceedings and to include new grounds in it. The grounds, which are under consideration, are connected to the decisions of the CCU and the ECtHR, which are called to perform the restorative role with respect to the court decisions that gained legal force.

The unconstitutionality of the law, another normative act or their separate provisions established by the CCU, are applied by the court for the resolution of the case (item 1, p. 3, Art. 459 of the CrPC of Ukraine) $)^{54}$ - propter decreta. The legal act is declared unconstitutional fully or in a specific part, if it does not comply with the Constitution of Ukraine or if the procedure of its review, approval or entry into force, established by the Constitution of Ukraine, was violated. The law (or its specific norms), which is declared unconstitutional, expires from the day when the decision is made on its unconstitutionality by the CCU. Therefore, it follows that the court decision, made by the court on the grounds of such a legal act, cannot be considered fair and enforceable. In order to correct the decision, the commencement of proceedings, based on exceptional circumstances, is required, to review the court decision and to make a corresponding decision by the competent court of the general jurisdiction.

This group of circumstances was also unknown to the court at the moment of making a decision, but possesses three properties that are uniquely inherent. Firstly, such circumstances are established not by the courts of the general jurisdiction, not by the pretrial investigation bodies or by the prosecutor, but by the other judicial body - the CCU. Secondly, such circumstances may improve or worsen the situation of the convict, the person about whom coercive measures of an educational or medical nature are applied, or the closed 
criminal proceedings. Meanwhile, it is worth mentioning that in the para. 2 Art. $540 \mathrm{CrPC}$ of the Republic of Poland (Kodeks postepowania karnego), establishing such circumstances is directed to improving the situation of the person and to knowingly resolving the result of the consideration of the criminal proceedings, which is required to end with an acquittal or the closure of the criminal proceedings $s^{55}$. Thirdly, the day of the discovery of such circumstances is considered the day when the decision of the CCU regarding the unconstitutionality of the legal act, applied during the criminal proceedings, gained the legal force.

Item 4, p. 2, Art. 459 of the CrPC of Ukraine does not say which law it mentions - material or procedural. In our opinion, the recognition of the provisions of the law of Ukraine on criminal liability as well as criminal procedure law as being unconstitutional, may serve as a ground for the proceedings based on exceptional circumstances.

Polish authors arrived at an identical conclusion when analysing a similar case in content para. 2 Art. 540 of the CrPC of the Republic of Poland. ${ }^{56}$

Having been established by the international judicial institution whose jurisdiction is recognized by Ukraine, there is a violation of international obligations by Ukraine when resolving such a case in court (item 2, p. 3, Art. 459 of the CrPC of Ukraine) ${ }^{57}$ - propter decreta. The violation of the ECHR, having been established by the ECtHR, requires rectifying in order to resolve relevant criminal cases in court. Having used the norm of law during the proceedings, the court was not aware of its partial or full non-compliance with the regulations of the ECHR.

A substantial influence on the implementation of this ground into the national legislation of European countries was carried out by the Council of Europe through its bodies. In particular, the Committee of Ministers mentioned repeatedly in its acts the necessity to create the mechanism in the national legislations of the participant countries of the Council of Europe to provide for the reconsideration of criminal proceedings in the case when the ECtHR makes the final decision, which states for the violation of human rights and freedoms.

Thus, in the Recommendation No. R (2000) 2, the Committee of Ministers encourages the contracting states to improve domestic law in order to ensure the resumption of proceedings in cases where the ECtHR has found violations of the ECHR which cannot be remedied other than by consideration of the case. In particular, when the appealed court decision does not comply with the ECHR or when there are significant procedural violations that call into question the justice of such a decision. ${ }^{58}$

In its turn, the Recommendation No. R (2004) 6, the Committee of Ministers recommends that member states ensure effective national remedies in case of violations of the provisions of the ECHR. The contracting parties should also, if necessary, improve or create new remedies in order to avoid possible violations of the ECHR in the future. ${ }^{59}$

55 Code of Criminal Procedure of Republic of Poland of 6 June 1997 No 89 'Kodeks postępowania karnego' (as amended of 19 August 2020) > accessed 20 February 2021.

56 A Bojańczyk, 'Wznowienie postępowania karnego na podstawie orzeczenia Trybunału Konstytucyjnego eliminującego przepis prawa procesowego z porządku prawnego' (2010) 1 Czasopismo Prawa Karnego i Nauk Penalnych 205.

57 Code of Ukraine (n 14).

58 Recommendation No R (2000) 2 of the Committee of Ministers to member states on the re-examination or reopening of certain cases at domestic level following judgements of the European Court of Human Rights <https://search.coe.int/cm/Pages/result_details.aspx?ObjectID=09000016805e2f06> accessed 20 February 2021

59 Recommendation $\operatorname{Rec}(2004) 6$ of the Committee of Ministers to member states on the improvement of domesticremedies $<$ https://search.coe.int/cm/Pages/result_details.aspx?ObjectId=09000016805dd18e > accessed 20 February 2021. 
Finally, in the Recommendation CM/Rec(2008)2, the Committee of Ministers recommends that the member states designate a coordinator with sufficient powers for the implementation of ECtHR decisions at a national level. ${ }^{60}$

The national legislation of most member states of the Council of Europe provides for the possibility of retrial and the reopening of proceedings on the basis of a decision of an international judicial body, in particular the ECtHR. According to the information of the Committee of Experts on the Reform of the Court ${ }^{61}$ thirty-three States allow the reopening of criminal proceedings. ${ }^{62}$ In thirty countries the reopening of criminal proceedings is provided for by laws. ${ }^{63}$ It is worth mentioning that Ukraine is one of those countries.

The regulation takes account of the fact that decisions adopted by the ECtHR do not have any direct cassation effect, and thus, acts of law adjudged to be in contravention of the convention still require annulment by the national courts. ${ }^{64}$

Seven models of the resumption of criminal proceedings on the grounds of the ECtHR's decision, which are based on three criteria, can be singled out. The first criterion is concerned with the source of the norms which form the grounds for the resumption of proceedings. This criterion singles out two models: the classical model and the model of dynamic court interpretation. The classical model provides for the existence of legal grounds for the resumption of criminal proceedings on the basis of the ECtHR's decision. The model of dynamic court interpretation is a model which does not include a clear legal ground for the resumption of the criminal proceedings on the basis of the ECtHR's decision. The resumption of the proceedings can only be done by the application of the corresponding dynamic court interpretation. The second criterion requires the existence of the specific ground to start the resumption of the proceedings. Scholars distinguish the model of the result and the model propter nova. In order to re-initiate proceedings, the model of the result requires the existence of the severe consequences of the violation that may be eliminated only by the resumption of the proceedings. The model propter nova does not establish directly the condition for the resumption of the proceedings on the basis of the ECtHR's decision, although it is about the decision of the ECtHR which states the violation of the ECHR either as a result of the statutory definition or a court interpretation of the ground for the resumption of propter nova - the precondition to the new facts, new circumstances or new information. Finally, the third criterion is based on the type of the body making a decision on the resumption of the proceedings. One distinguishes the court model (suitable for almost all countries), the prosecutor model (common in Latvia) and the commission model (typical of France and Norway). The last two models differ from the court model in the fact that it is not the court but the prosecutor or a specially created

60 Recommendation $\mathrm{CM} / \operatorname{Rec}(2008) 2$ of the Committee of Ministers to member states on efficient domestic capacity for rapid execution of judgments of the European Court of Human Rights $<$ https:// search.coe.int/cm/Pages/result_details.aspx?ObjectID=09000016805ae618> accessed 20 February 2021

61 Committee of Experts on the Reform of the Court (DH-GDR), Overview of the exchange of views held at the 8th meeting of DH-GDR on the provision in the domestic legal order for the re-examination or reopening of cases following judgments of the Court, Strasbourg 2016, para. $7<\mathrm{https} / / \mathrm{rm}$.coe.int/ CoERMPublicCommonSearchServices/DisplayDCTMContent?documentId=0900001680654d5a> accessed 20 February 2021.

62 Albania, Armenia, Austria, Belgium, Bosnia and Herzegovina, Croatia, Cyprus, Czech Republic, Denmark, Estonia, Finland, France, Georgia, Germany, Greece, Italy, Latvia, Lithuania, the Republic of Moldova, the Netherlands, Norway, Poland, Portugal, Romania, Russian Federation, San Marino, Serbia, Slovak Republic, Slovenia, Spain, Sweden, Switzerland, and Turkey.

63 Albania, Austria, Belgium, Bosnia and Herzegovina, Croatia, Cyprus, Estonia, Czech Republic, Denmark, Finland, France, Georgia, Germany, Greece, Latvia, Lithuania, the Republic of Moldova, the Netherlands, Norway, Poland, Portugal, Romania, Russian Federation, San Marino, Serbia, Slovak Republic, Slovenia, Spain, Switzerland, Turkey. 
with this aim commission that evaluates the statements on the resumption of proceedings on the basis of the ECtHR's decision. ${ }^{65}$

In contrast with the circumstances, provided in items 1, 4, p. 2, Art. 459 of the CrPC of Ukraine, the 'unconstitutionality, constitutionality of the law, other legislative act, or their specific provisions, established by the CCU, applied by the court for the resolution of the case' and the 'violation of the international obligations by Ukraine during the resolution of the case in court, established by the international judicial institution, whose jurisdiction is recognized by Ukraine', as a ground for the criminal proceedings based on exceptional circumstances did not exist during the consideration of the criminal proceedings, but appeared after the court decision was made and gained the legal force. Such circumstances do not signify to the judicial an error of a factual nature, but rather signify an error from the point of view of inconsistencies in legal regulation of the order of criminal proceedings and (or) application of law of the Constitution of Ukraine and the ECHR by the court. The court was not aware, when making a decision, that the legal norm being applied and its law enforcement activity. did not fully or partially comply with the Constitution of Ukraine or the ECHR. The Ukrainian legislator combined these circumstances into one group, calling them exceptional.

Similar to the aforementioned circumstances, from the point of view of the legal nature and the method of confirmation, is a circumstance, provided in item 3, p. 2, Art. 459 of the CrPC of Ukraine, the 'cancellation of the court decision which became a ground for the court sentence or ruling, that has to be reviewed' ${ }^{\prime 66}$. Such a circumstance is also discovered after the court decision is made and when there is no direct connection to the subject of proof in the criminal proceedings. Yet another common property of the analysed groups of the circumstances is the method of their establishment. The existence of such circumstances is certified in the decision of higher court (item 3, p. 2, Art. 459 of the CrPC of Ukraine), the decision of the CCU (item 1, p. 3, Art. 459 of the CrPC of Ukraine), the decision of the ECtHR (item 2, p. 3, Art. 459 of the CrPC of Ukraine). The decisions of the higher court include the sentence of the courts of appeal, decisions on the cancellation of court decisions and the closure of criminal proceedings or a decision on the cancellation of court decisions and the appointment of a new trial in the court of first instance, as well as decisions of the court of cassation on the cancellation of court decisions and the closure of criminal proceedings or the decision on the cancellation of court decisions and the appointment of a new trial in the court of first instance or the court of appeal. As a result, the circumstance, provided in item 3, p. 2, Art. 459 of the CrPC of Ukraine from the point of view of the logic of legislative terminology has to belong to extraordinary and not to newly discovered.

The Ukrainian criminal procedure legislation, for a long time, linked proceedings based on NDC with committing a criminal offence by someone among the subjects of criminal procedure and this connection had a significant influence on the justice of the court decision. However, after the changes in the CrPC of Ukraine by the law of 3 October 2017, the legislator establishes that committing the criminal offence by the participants of criminal procedure not only in item 1, p. 2, but also in item 3, p. 3, Art. 459 of the CrPC of Ukraine, thus establishing the guilt of the judge committing the criminal offence or abuse by the investigators, prosecutors, investigating judges or court during the criminal proceedings, which resulted in the court decision (propter crimina or propter falsa).$^{67}$

Item 3, p. 2, Art. 459 of the CrPC of Ukraine mentions such abuse by the investigators, prosecutors, investigating judges and court during the criminal proceedings that resulted in significant damage as one of the signs of criminal offences against the law. Therefore, it is more correct to speak about criminal and illegal abuses of the specified officials.

\footnotetext{
$65 \quad$ M Mrowicki (n 11) 73.

66 Code of Ukraine (n 14).

67 Ibid (n 14).
} 
Criminal and illegal abuses by the investigator and prosecutor during the criminal proceedings may consist of knowingly illegal detention, arrest, house arrest or remand (pretrial detention), imposition of the knowingly innocent to the criminal liability, forcing to testify by threatening, abusing, bullying the person, the violation of the right for defence, the falsification of the physical evidence, the protocols of procedural actions, the withdrawal of the documents, physical evidence from the materials of the criminal proceedings, etc. Evidence may also be falsified by inactivity (for example, the investigator refuses to add the documents that refute the already collected evidence, to the materials of the criminal proceedings). Apart from that, criminal and illegal abuses may mean giving the orders in a written form by the prosecutor which influence the illegal or unjustified decisions by the coroner, investigator, or NABU detective.

In the order de lege ferenda, one should add to the list of the specified officials during the pre-trial investigation, the official responsible for the procedural actions employee of the operational unit, coroner, the NABU detective, the head of the inquiry body, the head of the body of pre-trial investigation and the head of the body of prosecution.

Criminal and illegal abuses by the judges during the criminal proceedings may consist of the violation of the rights of defence, the falsification of documents, physical evidence, a journal of the court hearing and other materials of the criminal proceedings, the withdrawal of documents, physical evidence, making a knowingly unjust court decision, etc.

Injustice of a court decision may be manifested in the knowingly incorrect presentation of the facts, which happened in reality, the knowingly incorrect evaluations of such facts, the knowingly incorrect qualifications of the actions of the person, the convictions of the knowingly innocent or the acquittal of the knowingly guilty, the illegal or unjustified closure of criminal proceedings, the release from the deserved punishment of the guilty, and a conviction that does not correspond to the severity of the committed criminal offence and to the accused.

A significant indication that the actions mentioned above have been committed is self-interest or other personal interest. Therefore, the facts of the incorrect application of the law, the misevaluation of the evidence, unjustified sentencing, if there were no results from the criminal and illegal abuses by the judge, must not be considered to be exceptional circumstances.

The content of item 2, p. 2, Art. 459 of the CrPC of Ukraine is applied not only for the judges but also for the jury, since according to item 23, p. 1, Art. 3 of the CrPC of Ukraine the jury is equated to the judges. ${ }^{68}$

It is worth mentioning that p. 4, Art. 459 of the CrPC of Ukraine imposes that the person who applies the law needs to establish such a group of circumstances by the court decision that gained legal force, and in case of the impossibility of making the decision to confirm their existence by the court ruling or arrive at a decision on the closure of the criminal proceedings, or a decision on the application of coercive measures of a medical nature. A similar order of certification (confirmation) is defined also for the circumstances provided in item 1, p. 2, Art. 459 of the CrPC of Ukraine. ${ }^{69}$ From this point of view, it is surprising to relate the circumstances provided in item 3, p. 3, Art. 459 of the CrPC of Ukraine not with the newly discovered but with exceptional. Such circumstances already existed at the time of carrying out the court proceedings, but the court was not aware of them. Therefore, it was not possible for the court to take them into account when making a court decision.

In item 3, p. 3, Art. 459 of the CrPC of Ukraine the legislators separate 'establishing of the guilt of the judge in the committing of crime' and 'abuse of the investigating judge or court

$68 \quad$ Code of Ukraine (n 14).

69 Ibid (n 14). 
during the criminal proceedings which results in making the court decision'. However, the first circumstance is more abstract from the point of view of content and the legal consequences in this case are not defined in the context of chapter 34 of the CrPC of Ukraine. For example, tax evasion by the judge from paying alimony for child support (art. 164 of the CC of Ukraine) or a violation by him of the safety of traffic rules (Art. 286 of the CC of Ukraine) does not affect and may not affect the justice of the court decision. ${ }^{70}$ In the other cases, it is necessary to evaluate the legal situation connected to the establishment of the guilt of the judge in committing the criminal offence, for example, in the sphere of official and professional activity against the law. In such a case the connection between the publicly dangerous activity of the judge and legality, reasonableness and justice of the court decision, made by the judge, is highly possible. On the basis of the research of both criminal proceedings, the court that carries out the proceedings based on exceptional circumstances must answer the following questions: a) do the circumstances of the criminal and illegal abuse by the judge exist? b) have those circumstances had an influence on the justice of court decision made by the judge or might those circumstances have had an influence on the justice of court decision made by the judge? Therefore, in our opinion the phrase 'establishment of the guilt of the judge in committing the crime' has to be excluded from the edition of item 3, p. 3, Art. 459 of the CrPC of Ukraine.

The Ukrainian legislator separates in two groups the grounds for the proceedings on appeal and the verification of the court decisions, regulated in chapter 34 of the CrPC of Ukraine. NDC in their nature, their method of certification, their existence at the moment of making the court decisions and their belonging to the elements of the subject of proof in the criminal proceedings may be used for the interest of the convicted as well as against the interest of the convicted and may significantly differ from the ones that are called 'exceptional'. Therefore, in chapter 34 of the CrPC of Ukraine, two types of criminal procedure activity on appeal and the verification of court decisions that gained legal force are actually provided: the proceedings based on NDC and the proceedings based on exceptional circumstances.

\section{CONCLUSIONS}

Unlike the proceedings on appeal or cassation, the PBNDEC are carried out on the grounds of the discovery of such circumstances that either appeared after the trial or have already existed at the time of the trial but were not known to the court. In such cases, not all circumstances are taken into account but only those that do not allow the possibility to evaluate court decisions in criminal proceedings as legal, reasonable and fair. Therefore, the PBNDEC are motivated by a special nature with regard to court errors, having been introduced for their certification and elimination. The law enforcement errors of such a type require a detailed regulated order of criminal procedure activity.

The approaches to the understanding of the core principles of PBNDEC in the criminal procedure doctrine of European countries are very similar. European researchers are unanimous that such a procedural institute-as a guarantee of the balance between the universality of the court decision that gained the legal force and its verification in the specific cases under certain rules-must be considered. Such proceedings correspond with both the constitutional norms and the international obligations of the members of Council of Europe with respect to the principle of legal certainty in the national legislative systems. PBNDEC do not provide for the elimination of gaps and (or) correction of violations made during pre-trial investigation and court proceedings, but rather the determination of the facts and circumstances that due to objective and subjective reasons were not considered as a subject 
of investigation in the criminal proceedings before. Such a form of appeal and verification of court decisions puts beyond any doubt the resolution of the criminal proceedings at its core. Such a mechanism of criminal procedure may and should be applied by itself for the elimination of the violations, made during the criminal jurisdiction and not when the possibility of the elimination of the violations in the courts of appeal and cassation turned out to be exhausted. Therefore, with respect to the aforementioned proceedings such a mechanism should not be considered as being a reserve.

In the majority of European countries, the normative legal basis that allows for the possibility of the resumption of criminal proceedings on the basis of the ECtHR decision is implemented. However, the unique European model for the resumption of criminal proceedings on the basis of the ECtHR decision does not exist and every existing model is connected to the specifics of the national legislative system.

The legal regulation of the grounds for the PBNDEC in the criminal procedure law of Ukraine is not without drawbacks. Together with the drawbacks of a conceptual nature. the local miscalculations of the legislators, which can give rise to legal uncertainty, are also present. Therefore, legislative regulations for the PBNDEC in the criminal procedure law of Ukraine require complex and systematic improvement.

\section{REFERENCES}

1. Bojańczyk A, 'Wznowienie postępowania karnego na podstawie orzeczenia Trybunału Konstytucyjnego eliminującego przepis prawa procesowego z porządku prawnego' (2010) 1 Czasopismo Prawa Karnego i Nauk Penalnych 205.

2. Bouloc B, Procédure pénale, 24-e édition (Dalloz 2014).

3. Committee of Experts on the Reform of the Court (DH-GDR), Overview of the exchange of views held at the 8th meeting of DH-GDR on the provision in the domestic legal order for the re-examination or reopening of cases following judgments of the Court, Strasbourg 2016 <https://rm.coe.int/CoERMPublicCommonSearchServices/DisplayDCTMContent?doc umentld=0900001680654d5a $>$ accessed 20 February 202.

4. Fabrizy E, Kurzkommentar StPO 1975, 11, neu bearbeitete Auflage (Manz 2011).

5. Goetz $D$, La révision en matère pénale (Université de Strasbourg 2015).

6. Haller K, Conzen K, Das Strafverfahren 6, neu bearbeitete und erweiterte Auflage (CF Müller 2011).

7. Kołodziejczyk A, 'Wznowienie postępowania karnego na podstawie art 540 a pkt 1 kpk zagadnienia wybrane' (2010) 14 Studia luridica Lublinensia 161.

8. Lindemann M, Lienau F, 'Mechanisms for Correcting Judicial Errors in Germany' (2020) 4 (incomplete) Erasmus Law Review 1.

9. Mrowicki M, Wznowienie postępowania karnego na podstawie rozstrzygnięcia Europejskiego Trybunału Praw Człowieka (Rzecznik Praw Obywatelskich 2020).

10. Pradel J, Procédure pénale, 17-e édition (Éditions Cujas 2013).

11. Rassat M-L, Procédure pénale, 2-e édition (Ellipses Édition Marketing SA 2013).

12. Roxin C, Schünemann B, Strafverfahrensrecht, 27, neu bearbeitete Auflage (CH Beck 2012).

13. Spangher G, 'Impugnazioni straordinarie: aspetti sistematici di una categoria allargata' in Paola Corvi (ed), Le impugnazioni straordinarie nel processo penale (Giappichelli 2016) 1.

14. Tonini P, Manuale di procedura penale, Quindicesima edizione (Giuffrè Editore 2014).

15. Trestné právo procesné in Jaroslav Ivor (ed), Druhé, doplnené a prepracované vydanie (lura Edition 2010).

16. Trestné právo procesné. Všeobecná a osobitná čast' in Josef Čentéš (ed) 2 vydanie (Heuréka 2012). 